\title{
Macroeconomic Variables and Value Creation in the Nigerian Quoted Companies
}

\author{
Fatai Abiodun Atanda ${ }^{1}$, Taiwo Olufemi Asaolu ${ }^{1} \&$ Adewale Atanda Oyerinde ${ }^{1}$ \\ ${ }^{1}$ Obafemi Awolowo University, Ile Ife, Nigeria \\ Corresponding: Fatai Abiodun Atanda, Department of Management and Accounting, Obafemi Awolowo \\ University, Ile-Ife, Nigeria. Tel: 234-803-424-2773. E-mail: atanda200luk@yahoo.co.uk
}

Received: March 5, 2015

Accepted: March 25, 2015

Online Published: May 25, 2015

doi:10.5539/ijef.v7n6p252

URL: http://dx.doi.org/10.5539/ijef.v7n6p252

\begin{abstract}
This study uses 1,425 observations, relating to firm level and time series data sets, to examine the effect of macroeconomic variables on the economic value created by the Nigerian quoted companies. The data described macroeconomic variables such as inflation (INF), interest rates (INT), capital expenditure ratio of government (CAR) foreign exchange rates (FRXG), gross domestic product (GDPG) and the developments in the capital (CMKG) and labour market (LBMG) and the economic value added (EVA) by 186 purposively selected quoted companies for the years 2001-2012. To allow for comparison, the companies were categorized into two sub-sectors: manufacturing ( 715 observations) and services ( 710 observations). The study uses descriptive and inferential statistical tools such as mean, standard deviation, correlation, pooled ordinary least square (OLS) regression and generalized method of moments (GMM) techniques to analyze data. The study found that EVA followed an autoregressive function after one period and lagged EVA was included in model. Due to the problem of heteroskedasticity, Generalized Method of Moment results were relied upon and significant (positive and negative) impact of CAR $(\beta=-0.0173, \mathrm{p}<0.05)$, FRXG $(\beta=0.00857, p<0.01)$, INF $(\beta=-0.00896, p<$ $0.05)$, INT $(\beta=0.0262, p<0.1)$ and LBMG $(\beta=0.00158, p<0.01)$ on EVA was found, for all the companies. We concluded that value creation, measured by EVA, is a function of prior year EVA and that inflation rate, interest rate, foreign exchange rate, capital expenditure ratio and the development in labour market were important macroeconomic factors that should be improved upon if quoted companies were to optimally create economic value in Nigeria.
\end{abstract}

Keywords: value creation, macroeconomic variables, quoted company

\section{Introduction}

In recent times, the Nigerian economy had been growing and the contributions of the quoted companies cannot be overlooked. The companies have been recording operating results that demonstrated their value creating potentials and abilities to provide incomes (e.g. interests, taxes, dividends and salaries) to various stakeholders, which were reflected in their annual audited reports and accounts over the years 2001-2012.

However, no organizations exist in vacuum (Mullins, 1999); they take inputs from the environment and, through a series of activities, transform them into outputs that command prices in the markets. This means that the performance of the companies must have been influenced by factors that are within and outside their control. Environmental influences such as macroeconomic variables, competitors, infrastructures, government policies, regulations and reforms as well as individual firm characteristics such as assets, age and management structure have implications on the achievement of organizations' goals (Porter, Lawler, \& Hackman, 1975; Shirai, 2002; Adenikinju, 2005).

Heavy protection and regulations, which were the outcomes of the Nigeria's industrial policy, have impacted on the competitiveness of the manufacturing sector and economic fortunes, in terms of growth, employment, inflation, private credits and interest rates (Salawu, 2010), which have consequences on the ability of the Nigerian quoted companies to create economic value. Also, the move towards free markets (capital, money, labour, commodity and foreign exchange) since 2000, growth in credits to core private sector, capital expenditure of government, together with monetary policies might have provided ample opportunities to the Nigerian quoted companies to optimally create value. 
Moreover, series of consolidation and recapitalization were instituted to widen and deepen the financial system, especially in 2005. The reforms aimed at helping companies, operating in different sectors of the Nigerian economy to play an increasing and predominant role in value creation, employment and income generation, as well as expanding the size of the productive sector, generating tax revenue for the government and facilitating poverty reduction through fiscal transfers (Prasad, Green, \& Murinde, 2001). The operating environment of the Nigerian companies had therefore changed over the years 2001-2012, allowing more flexibility on how quoted companies create and distribute economic value.

There have been remarkable growth in the literature on how firm performance is measured and several arguments have been offered on the superiority of economic value added (EVA) over accounting metrics (Stewart, 1991; Elubar, 1998; Stern \& John, 2001). Besides, a plethora of studies had examined the factors that drive firm value with empirical evidences that they revolved around finance, growth, management and employees, products, assets, operating efficiency (Asogwa, 2009; Oba, 2011) and several firm-specific characteristics (Booth, 1998; Court \& Loch, 1999; Akalu, 2002; Kraai, 2006; Laitinen, 2008).

Though, these studies have broadened our understanding of the issues involved in value creation, most of the factors examined were internal to the companies. What is still not clear and which is equally important in sustainability accounting research agenda of the Nigerian quoted companies is the extent to which macroeconomic variables have been contributing to the economic value added by the companies over the years 2001-2012.

This study considered nine (9) macroeconomic variables such as interest rates, inflation rates, foreign exchange rates, money supply, private sector credits, gross domestic product, capital expenditure of government and the developments in the capital and labour markets to address the following questions: 1) Is there any significant impact of the macroeconomic variables on the economic value created by the Nigerian quoted companies? 2) If there is, do the macroeconomic variables affect the economic value created by companies operating in the manufacturing and service sectors the same way?

There have been links between corporate behaviour and macroeconomic stability of a country and it is our belief that the behaviour exhibited by the Nigerian quoted firms, operating in different economic sectors, in terms of the value created was affected by the changing macroeconomic environment, over the year 2001-2012. Besides, the Nigerian economy had been growing over the years and it is important to understand how the macroeconomic environment had impacted on the value creating abilities of the companies. The major proposition of this study is therefore that value creation (EVA) is a function of nine macroeconomic variables and this relationship was modeled using ordinary least square (OLS) linear regression equation.

\section{Conceptual and Literature Review}

Many scholars have conceptually addressed the issue of how firms create value (Booth, 1998; Bowman \& Ambrosini, 2000; Coff, 2005). In the literature, there is much debate and, arguably, some confusion about the concept of value (Lieberman \& Balasubramanian, 2007) and value creation. This is because scholars have often taken an overtly narrow view, equating value creation with returns to the ordinary shareholders (Booth, 1998; Kramer \& Pushner, 1997; Bowman \& Ambrosini, 2000), which means that the value created by a company belongs only to shareholders, thereby neglecting other stakeholders of the companies. This was caused by the belief held by most managers that the best way to increase firm value is to maximize short- term earnings in a predictable way, on behalf of the shareholders.

Value creation is the difference between inputs value and output value (Booth, 1998). From one period to the other, value is created (or destroyed) when revenue generated from a company's business activities is greater (or lesser) than the cost of purchased inputs or components used to generate outputs. It can also be measured by summing up factors payments such as total labour compensation, depreciation and amortization, rental payments, net income after taxes and all tax payments (Lieberman \& Chacar, 1997). The value referred to here is therefore the value created for all the stakeholders of a company and not necessarily shareholder' value, as used in some studies.

According to Lieberman and Balasubramania (2007), value creation means different things to different people. To customers, it means making products or providing services that they find consistently useful. To employees, it entails being treated with respect, being involved in decision making, excellent reward opportunities and continuous training and development. To investors however, value creation involves delivering, consistently, high returns on capital, which generally requires strong revenue growth and attractive profit margins that can be achieved only if a company sustainably delivers value. This therefore implies that a company's goal should be defined in terms of value adding activities rather than the traditional short-term financial performance. 
Ordinarily, managers are expected to pursue increased shareholders' wealth, earnings growth and returns on the assets employed. However, successful managers have come to realize that the purpose of a business is to create value for its stakeholders, irrespective of whether the stakeholders have financial claims against the business or not (Lieberman \& Balasubramania, 2007). The managers have therefore discovered that the traditional performance measures should not be the primary targets because they are merely rewards for aiming at the real target; that is, adding maximum value to the business.

According to Porter, Lawler and Hackman (1975), there are some environmental influences, which an organization should deal with. They further posited that only organizations whose internal features best match the demands of their environment and whose structure is properly designed to meet the challenges of the changes that occur both within and outside the organization can achieve the best. This had therefore put more responsibilities on managers on how to address the problem of instability in several macroeconomic variables such as increased interest and inflation rates that are externally foisted on companies, in order to achieve objectives such as profit or wealth maximization or any other economic, financial or non-financial goals.

The stability of the macroeconomic environment had been identified as an important factor for sustainable performance of firms and for the overall competitiveness of an economy. In fact, businesses are best conducted in an environment of stability with a minimum level of uncertainty (Adenikinju, 2005). There is therefore no doubt that the interference of government in various markets can bring about distortions in value creating potentials of businesses, their growth rates and sizes and the economy of a country at large.

It is evidenced in the literature that government's efforts at promoting economic development, by controlling macroeconomic variables such as interest rates and securing inexpensive funding for their own activities, have undermined financial development (Shirai, 2002; Salawu, 2010). This is because rigid controls and rules over interest rates, exchange rates, inflation rates and the capital market beyond the equilibrium level that market forces would dictate, have resulted in low direct investments in Nigeria (Salawu, 2010), with consequences on commodity and labour markets. There is therefore the need to determine the extent to which macroeconomic variables influenced the economic value created by quoted companies in Nigeria.

\section{Data and Methods}

\subsection{The Macroeconomic Variables}

The macroeconomic variables chosen for this study were drawn from the variables identified in Rose, Wesley and Giroux (1982), McNamara and Duncan (1995), Gunu and Idris (2009), Akinlo (2012), Omojimite (2012) and Odior (2013). The measures of the economic variables was also drawn based on the theories of market and price (developments in the capital, labour, money and foreign exchange markets), monetary economics (inflation, money supply and credits to core private sectors) and theory of public goods (capital expenditure of government) and output factor (gross domestic product). These variables have been theoretically posited and found to have impact on firm performance, however with mixed results.

\subsection{Theoretical Model}

Generally, economic value added (EVA) is modeled as a function of the macroeconomic variables as follow:

$$
E V A_{i t}=f\left(M A C_{i t}\right)
$$

where, EVA is the economic value created by company $i$ at time $t$ and $M A C$ contains the macroeconomic variables proposed to affect the behaviour of company $i$ at time $t$.

We initially considered nine macroeconomic variables, that is interest rates, inflation rates, foreign exchange rates, money supply, private sector credits, nominal gross domestic product, ratio of capital to total expenditure of government, developments in capital and labour markets, over the years 2001-2012. However, the different levels at which the variables were measured and the strong trend in most of them suggested that they cannot be used directly in the model, Hence, percentage change in foreign exchange rates growth (FRXG), money supply growth (MSG), private sector credits growth (PSCG), nominal gross domestic product growth (GDPG), capital market growth $(\mathrm{CMKG})$ and growth rate of employees' remuneration in the labour market (LBMG) and the ratio of capital expenditure to total expenditure of government (CAR) were used while inflation (INF) and interest rates (INT) were used directly. This is consistent with most economic and financial models.

The key endogenous variable was the economic value added (EVA), that is, the wealth created by the companies in each of the years covered by this study, which was measured by the proportion of EVA to net sales. Linear relationship for the equation was adopted because of its simplicity and efficacy in forecasting and because economic value was both created (positive) and depleted (negative) by the companies during the years covered 
by this study, which prevented us from using any other kinds of relationship like log-linear approach.

EVA was theoretically modeled as a function of macroeconomic variables (MAC) with the intention that all the nine variables, used to capture the exogenous variable, will be included. However, correlation results (as will be seen later) suggested that two out of the nine macroeconomic variables should not be included in the model, that is, MSG and PSCG. Not only that these variables were highly correlated with each other, they also exhibited high correlation with three other variables, that is, CAR, FRXG and CMKG.

While the correlation analysis identified the exogenous variables for the linear equation model, there was little or no guidance as to the process that generated the EVA series, which may have followed a moving average (MA) or autoregressive (AR) or mixed process. Thus, we explored the time series properties of EVA, using the Box-Jenkins Q-statistics methods. The autocorrelation and partial autocorrelation functions were plotted and the graph indicated that EVA followed an autoregressive function AR(1) after one period because the pike flattens after the first lag. Hence, one period lag of EVA was included as exogenous variable in the model. Equation (1) was therefore re-specified as follows:

$$
\begin{gathered}
E V A_{i t}=a_{0}+\beta_{1} I N T_{i t}+\beta_{2} I N F_{i t}+\beta_{3} F R X G_{i t}+\beta_{4} G D P G_{i t}+\beta_{5} C A R_{i t}+\beta_{6} C M K G_{i t}+\beta_{7} L B M G_{i t}+ \\
\beta_{8} E V A_{i t-1}+\eta_{i t}
\end{gathered}
$$

where, $\beta_{1}$ are the coefficients of the exogenous variables, $a o$ is the constant and $\eta$ is the stochastic error term of the model for company $i$ at time $t$.

\subsection{The Sample}

This study uses a total of 1,425 observations for firm year and macroeconomic data, covering the period 2001-2012, for analysis. Macroeconomic data were collected from the Statistical Bulletin of the Central Bank of Nigeria, 2012 and the firm year data on EVA were gathered from audited annual financial statements of 186 purposively-selected quoted companies in Nigeria; based on availability of data at the Nigerian Stock Exchange (NSE). The sample size therefore represents more than 70 percent of all the quoted companies in Nigeria. The sample was later divided into two sets of data to allow for different estimations for manufacturing companies (715 observations) and service companies (710 observations). The period 2001-2012 was chosen because it coincided with the periods when the Nigerian economy witnessed increased growth in all markets (commodity, money, labour and capital) which made the operating environment of quoted companies to change, significantly.

\subsection{Mode of Analysis}

Pooled data was used in this study because data could not be collected for all the companies and the years covered by this study, which resulted into missing data for endogenous variable, EVA. Pooled data also has a potential to remedy near multicollinearity problem (Brooks, 2008) because large data were involved and the degree of freedom increased. Apart from the descriptive statistics, data analysis was carried out in two stages: 1) Correlation matrix that showed pairwise relationships among the exogenous variables i.e. macroeconomic variables. This was to examine any incidence of multicollinearity and to produce a reduced set of macroeconomic factors to be used in regression model. 2) Regressing EVA and the macroeconomic factors using OLS and GMM estimation techniques. Before arriving at the final model, residual diagnostic test was carried out to ensure that the estimates obtained were reliable and consistent.

\section{Results and Discussions}

\subsection{Descriptive Statistics}

The descriptive statistics of the variables are as presented in Table 1. Mean value for LBMG was the highest among the exogenous variables; followed by CMKG and PSCG, indicating that the developments in the labour market, capital market and growth rate of the credits to private sector were rapid than others. These results were supported by the variables' standard deviations and ranges. While standard deviation indicated the dispersion of each variable's value to its mean $r$ the volatility in the markets' development and credits growth rate, range showed the differences between the lowest and highest values of the variables, which were much wider than any other variables in this study.

None of the variables were normally distributed as the data in the table provided information that suggested high Jarque-Bera statistics with p-values $<0.001$, which indicated rejection of null hypothesis of the presence of normality in data series in each case. This is typical of financial data because companies' behaviour can change at any time, which can lead to an unexpected poor or better performance. Also, most of the variables were positively skewed except inflation rate that was negatively skewed. 
Table 1. Descriptive analysis results

\begin{tabular}{lllllllllll}
\hline Statistics & EVA & CAR & CMKG & FRXG & GDPG & INF & INT & MSG & LBMG & PSCG \\
\hline Mean & 0.1865 & 2740 & 39.853 & 3.9345 & 21.285 & 12.573 & 18.214 & 25.005 & 66.052 & 33.572 \\
Median & 0.0108 & 28.510 & 40.270 & 2.3700 & 22.780 & 12.590 & 17.590 & 28.070 & 10.780 & 27.380 \\
Maximum & 16.5238 & 43.090 & 159.61 & 25.580 & 46.290 & 18.890 & 24.850 & 54.740 & 306.58 & 78.720 \\
Minimum & -0.9010 & 19710 & -28.070 & -5.770 & 2.0500 & 5.4200 & 15.140 & 3.2900 & -35.990 & 9.0200 \\
Std. Dev. & 0.1806 & 6.3471 & 53.884 & 8.6866 & 13.354 & 3.7003 & 2.3607 & 14.723 & 99.3897 & 22.058 \\
Skewness & 11.2926 & 0.3781 & 0.7328 & 1.4391 & 0.1511 & -0.240 & 1.3921 & 0.3780 & 1.27212 & 0.9466 \\
Kurtosis & 183.379 & 2.6674 & 3.1067 & 4.3656 & 1.9575 & 2.6147 & 5.0443 & 2.5178 & 396.317 & 221.24 \\
Jarque-Bera & 1962156 & 40.514 & 128.220 & 602.60 & 69.939 & 22.489 & 708.376 & 47.730 & 396.317 & 221.24 \\
Prob. & 0.0000 & 0.0000 & 0.0000 & 0.0000 & 0.0000 & 0.0000 & 0.0000 & 0.0000 & 0.0000 & 0.0000 \\
Observation & 1,425 & 1,425 & 1,425 & 1,425 & 1,425 & 1,425 & 1,425 & 1,425 & 1,425 \\
Cross-section & 186 & 186 & 186 & 186 & 186 & 186 & 186 & 186 & 186 \\
\hline
\end{tabular}

Source: Computations from E-view by the authors, 2014.

\subsection{Correlation Analysis Results}

The data in Table 2 showed the pairwise degree of association among the exogenous variables, that is, the macroeconomic variables. The results indicated very low magnitudes for most of the variables except for MSG and PSCG, FRXG and MSG, CAR and PSCG and CMKG and LBMG that were highly correlated with each other, in that order. While a large number of negative relationships were recorded, there were also positive relationships among the variables. For example, GDPG was negatively correlated with four variables (CAR, FRXG, MSG and PSCG) and positively correlated with the other four (CMKG, INF, INT and LBMG). However, CMKG positively correlated with five variables (GDPG, INT, LBMG, MSG and PSCG) but negatively correlated with three variables (CAR, FRXG and INF). The results therefore showed how the variables co-moved during the period under study and had implications on the variables that were included in regression model.

Table 2. Correlation results

\begin{tabular}{|c|c|c|c|c|c|c|c|c|c|}
\hline Variables & CAR & CMKG & FRXG & GDPG & INF & INT & LBMG & MSG & PSCG \\
\hline CAR & 1.000 & & & & & & & & \\
\hline CMKG & -01581 & 1.0000 & & & & & & & \\
\hline FRXG & 0.2152 & -03772 & 1.0000 & & & & & & \\
\hline GDPG & -0.4421 & 0.1116 & -0.3844 & 1.0000 & & & & & \\
\hline INF & 0.1113 & -0.4186 & 0.2676 & 0.1646 & 1.0000 & & & & \\
\hline INT & -0.0198 & 0.0194 & 0.4618 & 0.4699 & 0.2955 & 1.0000 & & & \\
\hline LBMG & -0.1314 & 0.6332 & -0.2836 & 0.1803 & -0.3434 & -0.0807 & 1.0000 & & \\
\hline MSG & 0.2887 & 0.1858 & -0.6995 & -0.1475 & -0.3057 & -0.4869 & -0.0751 & 1.000 & \\
\hline PSCG & 0.6963 & 0.1316 & -03021 & -0.3592 & -0.2890 & -0.3687 & -0.1916 & 0.7215 & 1.0000 \\
\hline
\end{tabular}

Source: Computations from E-view by the authors, 2014.

\subsection{Regression Results}

Equation model (2) was estimated using pooled cross-sectional time series data and initially by using OLS pooled estimation technique. Pooled regression is appropriate where a researcher is interested in population regression coefficients, drawn from a population rather than obtaining different individual company's regression coefficient using time series data of each company or common coefficient for all companies at a time using cross-sectional data. By using pooled data, a more efficient estimator $\beta_{1}$ can be obtained (Brooks, 2008).

However, the disturbance term vector $\eta$ was assumed to be cross-sectionally homoskedastic, that is, has a constant variance and was time-series uncorrelated i.e. autocorrelated. Should these classical regression assumptions violated by the model, the ordinary least square (OLS) estimates for the pooled data will be inefficient. Thus, residual diagnostic tests, such as serial correlation (using Breusch-Pagan-Godfrey methods) and heteroskedasticity (using White, 1990 method) were carried out to examine possible violation of the assumptions concerning the disturbance term. 
The series of tests revealed serial correlation with the Breusch-Pagan-Godfrey LM test statistic being insignificant $\left(\chi^{2}=0.475, \mathrm{p}>0.1\right)$ for all companies; significant serial correlation $\left(\chi^{2}=321.475, \mathrm{p}<0.01\right)$ for manufacturing companies and insignificant serial correlation $\left(\chi^{2}=0.119, p<0.01\right)$ for services companies. These results were respectively supported by their F-statistics. The White (1990) test statistic for heterogeneous disturbances (and other possible misspecifications), for all companies $\left(x^{2}=1107.93, p<0.01\right)$ suggested that the null hypothesis should be rejected. That is, the disturbance terms for the OLS models were not homoskedastic, as there are some evidences of significant heteroskedasticity. In fact, both the F-statistic $(\mathrm{F}=620.001, \mathrm{p}<0.01)$ and Scaled explained SS $\left(\chi^{2}=83607.23, \mathrm{p}<0.01\right)$ supported the results.

Also, for manufacturing companies $\left(\chi^{2}=36.152, \mathrm{p}<0.01\right)$ and services companies $\left(\chi^{2}=554.717, \mathrm{p}<0.01\right)$, the White (1990) test indicated significant heteroskedasticity in error terms, respectively. The F-statistics (F-stat. $=4.700, \mathrm{p}<0.01$ and F-stat. $=314.601, \mathrm{p}<0.01$, respectively $)$ and Scaled explained SS statistics $\left(\chi^{2}=5645.515\right.$, $\mathrm{p}<0.0$ I and $\chi^{2}=20465.49, \mathrm{p}<0.01$, respectively) for the two categories of companies also supported the results. The presence of significant serial correlation in the disturbance terms for the manufacturing companies must have contributed to the overall results obtained for all the companies.

To overcome these problems, a different estimation technique that incorporated information about the structures of the disturbance terms and that produced more efficient and reliable estimates for beta coefficient was used. The structural equation model was therefore re-estimated using the generalized method of moments (GMM) with adjustment for heteroskedasticity errors. This technique was selected because of the lagged dependent variable included in model as explanatory variable and because the method has the ability to provide information about the dynamic relationship between the endogenous and exogenous variables (Brooks, 2008).

The results obtained from model estimation using OLS and GMM were reported in three panels in Tables 3 and 4 , respectively. The first panel in Table 3 showed results for all companies and the second for manufacturing sector while the third is for services sector (banks, insurance and trading companies). A quick glance at the results in the table revealed that the coefficients were statistically significant at 1,5 and 10 percent levels and the fit was very tight with adjusted R-squares of $0.4771,0.9597$ and 0.4654 for all companies, manufacturing and service companies, respectively.

However, since the error term is serially correlated, the estimated OLS standard errors were invalid and the estimated coefficients were biased and inconsistent, due to the presence of a lagged dependent variable on the right- hand side. The Durbin-Watson statistics were therefore not appropriate in testing for serial correlation. Statistics of 2.007, 2.009 and 0.575, respectively, supported the outcomes of the Breusch-Pagan-Godfrey's LM test for serial correlation because no significant serial correlation was detected for all companies and services companies but significant serial correlation in error terms was detected for manufacturing companies.

The data in Table 4 (1st column) showed significant explanatory power at 1, 5 and 10 percents for most of the variables except CMKG (capital market growth used to measure the developments in capital market) and GDPG that showed insignificant relationship with EVA. In fact, the variables did not make meaningful contribution to the value created by all the companies during the periods, given the size of their coefficients $(\beta=0.00138, p>0.1)$ and $(\beta=0.00283, p>0.1)$ for CMKG and GDPG, respectively. In the same vein, CMKG $(\beta=0.000131, \mathrm{p}>0.1)$ and GDPG $(\beta=0.000627, \mathrm{p}>0.1)$ did not have significant impact on the value created by manufacturing companies while GDPG $(\beta=0.00771, \mathrm{p}<0.05)$ had positive and significant impact on the value created by companies in the services sector.

Though, the contribution was very small and less than $1 \%$, this result for the services sector supported the findings of McNamara and Duncan (1995) that increases in the level of economic activities, as measured by GDP, are accompanied by increases in companies' performance. The result also provided the notion that increases in economic activity flew through to sales and thus positively affected the economic value created by the companies operating in the services sector of the Nigerian economy. 
Table 3. Pooled OLS regression results

Dependent variable: EVA

\begin{tabular}{lccc}
\hline Variables & All Companies & Manufacturing Sector & Services Sector \\
\hline Constant & 01386 & $0.01698^{* * *}$ & 0.2262 \\
& $(0.68)$ & $(-1.65)$ & $(0.54)$ \\
EVA(-1) & $0.68388^{*}$ & $5.57 \mathrm{E} 02^{*}$ & $0.6829^{*}$ \\
& $(35.47)$ & $(5.94)$ & $(24.69)$ \\
CAR & $1.95 \mathrm{E}-04$ & $3.19 \mathrm{E} 04^{* *}$ & $1.74 \mathrm{E}-03$ \\
& $(0.07)$ & $(-2.07)$ & $(0.29)$ \\
CMKG & $1.34 \mathrm{E}-04$ & $-8.43 \mathrm{E}-07$ & $7.70 \mathrm{E}-05$ \\
& $(0.28)$ & $(-0.03)$ & $(0.08)$ \\
FRXG & $3.04 \mathrm{E}-03$ & $2.10 \mathrm{E}-04$ & $5.68 \mathrm{E}-04$ \\
& $(0.73)$ & $(0.90)$ & $(0.07)$ \\
GDPG & $3.55 \mathrm{E}-03$ & $-6.07 \mathrm{E}-05$ & $5.88 \mathrm{E}-03$ \\
& $(1.24)$ & $(-0.40)$ & $(1.05)$ \\
INF & $12 \mathrm{E} 02^{* *}$ & $1.85 \mathrm{E}-04$ & $0.0207 * *$ \\
& $(-2.29)$ & $(-0.75)$ & $(-2.04)$ \\
INT & $-5.91 \mathrm{E}-03$ & $1.38 \mathrm{E}-03$ & $-6.16 \mathrm{E}-03$ \\
& $(-0.38)$ & $(1.71)$ & $(-0.20)$ \\
LBMG & $1.05 \mathrm{E} 03^{*}$ & $1.15 \mathrm{E} 05^{*}$ & $9.05 \mathrm{E} 04^{* *}$ \\
& $(4.80)$ & $(88.99)$ & $(2.05)$ \\
Adjusted R-square & 0.48 & 0.96 & 0.47 \\
Schwarz Criterion & 1.74 & -4.87 & 2.45 \\
F-Statistics & 163.23 & 2121.24 & 78.04 \\
Durbin-Watson & 2.007 & 0.58 & 2.009 \\
Cross section & 186 & 84 & 102 \\
No. of observation & 1425 & 715 & 710 \\
\hline
\end{tabular}

Source: Computations from E-view by the authors, 2014.

Note. the figures in parentheses indicate t-statistics. *,** and indicate significance at $1 \%, 5 \%$ and $10 \%$ levels, respectively.

The contribution of one year lag EVA was positive $(\beta=0.7927, \mathrm{p}<0.01)$, its impact on current year EVA was also statistically significant and high, which means that the value created in the immediate past year by the companies had noticeable impact on the subsequent year's value being created. The same situation applied to the results obtained for manufacturing $(\beta=0.5044, \mathrm{p}<0.01)$ and services $(\beta=0.7340, \mathrm{p}<0.01)$ companies. The manner in which economic value is appropriated might have contributed to this result. Perhaps, the value distributed to critical stakeholders of the companies, like employees, favoured the creation of greater value.

The data in the table further provided evidence that inflation positively and significantly affected the manufacturing companies $(\beta=0.00155, \mathrm{p}<0.05)$ but negatively affected the companies in the services sector ( $\beta=-0.00917, \mathrm{p}<0.1)$, though not significant. The negative results for $\operatorname{CAR}(\beta=-0.0173, \mathrm{p}<0.05), \mathrm{CMKG}$ $(\beta=-0.00138, \mathrm{p}>0.1)$ and INF $(\beta=-0.00896, \mathrm{p}<0.05)$ were inconsistent with the apriori expectation that these macroeconomic variables will have significant positive effects on the wealth created by the companies, as depicted in the structural equation model specified in this study.

While the developments in the capital market (CMKG) since 2001 to 2012 did not have any significant effect on the wealth created by the Nigerian quoted companies (manufacturing and services), the developments in the foreign exchange market $(\beta=0.00857, \mathrm{p}<0.01)$ and labour market $(\beta=0.00158, \mathrm{p}<0.01)$ however had positive, high and significant effect. It is usually expected that interest rates (INT) will have significant negative effect on firm performance through their impact on cost of factors of production, which means that the higher the interest rates, the lower the firm performance.

However, since EVA is the difference between input value and output value, it was apriori expected that interest rates' effect on EVA will be positive. The data in the table provided information that was not inconsistent with the expectation because the variable had positive and significant impact $(\beta=0.0112, \mathrm{p}<0.01)$ on the wealth created by the manufacturing companies and positive but statistically insignificant effect on the wealth created by services companies $(\beta=0.00703, \mathrm{p}>0.1)$, even at $10 \%$ level. 
Table 4. GMM regression results

Dependent variable: EVA

\begin{tabular}{lccc}
\hline Variables & All Companies & Manufacturing Sector & Services Sector \\
\hline EVA(-1) & $0.7927^{*}$ & $0.5044^{*}$ & $0.7340^{*}$ \\
CAR & $(7.19)$ & $(4.53)$ & $(6.35)$ \\
& $-1.73 \mathrm{E}-02^{* *}$ & $-8.30 \mathrm{E}-03^{*}$ & $1.50 \mathrm{E}-04$ \\
CMKG & $(-2.49)$ & $(-4.23)$ & $(0.03)$ \\
& $-1.38 \mathrm{E}-03$ & $1.31 \mathrm{E}-04$ & $1.05 \mathrm{E}-03$ \\
FRXG & $(-1.30)$ & $(0.99)$ & $(0.87)$ \\
& $8.57 \mathrm{E}-03^{*}$ & $7.94 \mathrm{E}-03^{*}$ & $1.18 \mathrm{E}-02^{* *}$ \\
GDPG & $(2.64)$ & $(3.55)$ & $(1.89)$ \\
& $2.83 \mathrm{E}-03$ & $6.27 \mathrm{E}-04$ & $7.71 \mathrm{E}-03^{* *}$ \\
INF & $(1.63)$ & $(-1.03)$ & $(1.94)$ \\
& $-8.96 \mathrm{E}-03^{* *}$ & $1.55 \mathrm{E}-03^{* *}$ & $-9.17 \mathrm{E}-03$ \\
INT & $(-2.18)$ & $(-2.20)$ & $(-1.03)$ \\
& $2.62 \mathrm{E}-02^{* * *}$ & $1.12 \mathrm{E}-02^{*}$ & $7.03 \mathrm{E}-03$ \\
LBMG & $(1.84)$ & $(2.74)$ & $(-0.40)$ \\
& $1.58 \mathrm{E}-03^{*}$ & $1.25 \mathrm{E}-03^{*}$ & $5.54 \mathrm{E}-04^{* *}$ \\
Adjusted R-square & $(4.76)$ & $(21.79)$ & $(2.10)$ \\
J-Statistics & 0.43 & 0.47 & 0.45 \\
P-values (J-stat.) & 5.73 & 3.51 & 2.93 \\
Instrument Rank & 0.057 & 0.0608 & 0.087 \\
Durbin-Watson & 10 & 9 & 9 \\
Cross section & 2.15 & 2.54 & 2.11 \\
No. of observation & 186 & 84 & 102 \\
\hline
\end{tabular}

Source. Computations from E-view by the authors, 2014.

Note. Figures in parentheses indicate t-statistics. *, ** and *** indicate level of significance at $1 \%, 5 \%$ and $10 \%$, respectively.

The adjusted R-squares for the GMM models indicated that the variables accounted for 43, 47 and 45 percents, respectively of the overall variations in the wealth created by all, manufacturing and services companies. Also, J-statistics showed that the variables included in the models were good. This was confirmed by the instrument rank of 10, 9 and 9 for the three models, respectively. To ascertain that the final models were reliable and consistent, orthogonality test was carried out for all the instrumental variables and the results obtained (not reported) indicated that the null hypothesis should be rejected.

\section{Summary and Conclusion}

The purpose of this study was to examine the impact of macroeconomic variables on the wealth created by the Nigerian quoted companies over the years 2001-2012. We used secondary data that described dependent variable, that is, EVA and nine macroeconomic variables as the independent variables and the data were analyzed using descriptive and inferential statistical tools such as mean, standard deviation, correlation and OLS and GMM regression techniques.

The study found rapid growth in the developments in labour market, in terms of employees' compensation, over the years 2001-2012 more than the other macroeconomic variables included in this study. Time series properties of the endogenous variable, that is, EVA were explored using Box-Jenkins Q-statistics and the results showed that the variable followed an autoregressive function $\operatorname{AR}(1)$ after one period hence, one-year lagged EVA was included in the model estimated.

Significant serial correlation in data series was also detected for manufacturing companies but insignificant serial correlation detected in the data series collected from service companies using Breusch-Pagan-Godfrey LM and White tests. The estimates obtained from OLS regression method using pooled data were then considered biased, inconsistent and unreliable hence, the use of GMM estimation technique.

The results obtained from GMM technique showed significant and positive contributions of one year lag EVA on current year EVA for the companies operating in manufacturing and services sectors. The lead lag model suggested that a forecast of the value creation potentials of the Nigerian quoted companies can be made based on 
the model presented in this study. We also found significant impact (positive and negative) of capital expenditure ratio, foreign exchange rates growth, inflation rates, interest rates and the developments in labour market on the value created by the Nigerian quoted companies. This showed that improvements in these macroeconomic variables can account for higher value being created by the companies.

Whereas, foreign exchange rates growth, gross domestic product growth and the developments in labour market had positive impact on the value created by the companies, capital expenditure ratio and inflation rates growth had significant negative impact. Also, capital expenditure ratio had significant negative effect on the economic value created by manufacturing companies. Though, the magnitude was very low, inflation rates had significant positive impact on the value created by the manufacturing companies and its effect on the value created by service companies was insignificant. In addition, residual statistics such as the adjusted R-square, J-statistics and orthogonality tests results indicated that the variables included in this study were good, fit, reliable and consistent.

Based on the major findings of this study, we concluded that value creation, measured by EVA, is a function of prior year EVA and that macroeconomic variables such as inflation rates, interest rates, foreign exchange rates growth, capital expenditure ratio and the developments in the labour market are important macroeconomic factors to be improved upon if quoted companies are to optimally create economic value in Nigeria.

Different policy implications can emerge from this study. Firstly, the companies should develop policies aimed at promoting the identification and exploitation of value adding economic activities in terms of innovation and research and development (production and marketing) activities to improve performance since prior year EVA had significant and positive impact on current year EVA. Secondly, the significant impact of the development in the foreign exchange market on EVA indicated that the development in the Nigerian economy during these periods necessitated investment opportunities that required the use of foreign currencies by the companies, which consequently brought about increased economic value being created. Hence, government should design and tailor regulatory policies towards enhancing its efficiency and increasing the positive effects of foreign exchange market on the value creating potentials of the companies.

Thirdly, free markets (money, labour and foreign exchange) should be encouraged and policy measures capable of removing barriers to their operations such that their efficiency can be enhanced should be developed by the government. Any instability in inflation, interest rates and foreign exchange rates should also be promptly addressed. Government interference should however be guided by sound economic principles and appropriate consideration to the different demands of each sector of the Nigerian economy. Finally, the discrepancies in the magnitudes and signs of the impact of most of the macroeconomic variables on the value created by manufacturing and services companies (most importantly gross domestic product, interest rates, inflation rates and capital expenditure ratio) signified the fact that government policies affected different sectors differently. Hence, future policies should take this into consideration both at the planning and implementation stages.

\section{References}

Adenikinju, A. (2005). Productivity Performance in Developing Countries. Country Case Studies, Nigeria. Retrieved from http://www.unido.org/fileadmin/user media/publication

Akalu, M. (2002). Measuring and Ranking Value Drivers. A Discussion Paper. The Timbergen Institute for Economic Research of the Erasmus University, Amsterdam.

Akinlo, A. (2012). The Determinants of Trade Credit: Evidence from Nigerian Manufacturing Firms. Economic Journal of A2Z, 1(1), 31-42.

Asogwa, R. (2009). Measuring the Determinants of Value Creation for Publicly Listed Banks in Nigeria: A Random Effects Probit (REP) Model Analysis. Paper Presented at the 8th Annual Conference of Econometric Modeling for Africa, 8-10th July.

Benett, M., \& James, P. (1999). Sustainable Measures, Evaluation and Reporting of Environmental Lend Social Performance. Greenleaf: Sheffield.

Booth, L. (1998). What Drives Shareholder Value? Paper Presented at the Federated Press Creating Shareholder Value Conference. Toronto, Canada. October.

Bowman, C., \& Ambrosini, V. (2000). Value Creation versus Value Capture: Towards a Coherent Definition of Value in Strategy. British Journal of Management, 11(1), 1-15.

Central Bank of Nigeria. (2012). The Statistical Bulletin. Abuja. Central Bank of Nigeria Publication.

Coff, R. (2005). What is Competitive Advantage in a Multi-stakeholder Inter-temporal World? A Working Paper. 
Court, D., \& Loch, M. (1999). Capturing the Value. Advertising Age, 70(46), 46.

Easterly, W. (2005). National Policy and Economic Growth. In P. Aghion \& S. Durlauf (Eds.), Handbook of Economic Growth. Elsevier.

Elkington, J. (1994). Towards the Sustainable Corporation: Win-win-win Business Strategies for Sustainable Development. California Management Review, 36(2), 90-100.

Elkington, J. (1997). Cannibals with Forks. The Triple Bottom Line of 21st Century Business. Oxford: Capstone.

Elubar, A. (1998). EVA: The Real Key to Creating Wealth. New York: John Wiley.

Kaplan, R., \& Norton, D. (1992). The Balanced Scorecard: Measures that Drive Performance. Harvard Business Review, 70(1), 71-79.

Kaplan, R., \& Norton, D. (2004). Strategy Maps: Converting Intangibles Assets into Tangible Outcomes. Boston MA: Harvard Business School Press.

Kraai, J. (2006). Value Drivers- How Do They Affect Your Business' Value? Vancouver Business Journal, 1-16.

Kramer, J., \& Pushner, G. (1997). Empirical Analysis of Economic Value Added As A Proxy for Market Value Added. Financial Practice and Education, 7(1).

Laitinen, E. (2008). Value Drivers in Finnish Family-Owned Firms: Profitability, Growth and Risk. $J$. Accounting and Finance, 1(1), 1-41.

Lambert, D., \& Burdurgolo, R. (2000). Measuring and Selling the Value of Firms. International Journal of Logistics Management, 11(1), 1-17.

Lieberman, M, \& Charcar, A. (1997). Measuring the Distribution of Returns Among Stakeholders, Methods and Application to US and Japanese Companies. In H. Thomas, D. O’Neal, \& R. Alvarado (Eds.), Strategic Discovery: Competing in New Arenas. New-York: John Willey \& Sons.

Lieberman, M., \& Balasubramanian, N. (2007). Measuring Value Creation and Its Distribution Among Stakeholders of the Firm. Paper Presented at the Academy of Management Annual Meeting, 2005 and the Atlanta Competitive Advantage Conference in 2007.

McNamara, R., \& Duncan, K. (1995). Firm Performance and Macroeconomic Variables. School of Business Discussion Paper No. 66. Retrieved from http//epublications.bond.edu.au/discussion papers/66

Mullins, L. (1999). Management and Organizational Behaviour (5th ed.). Great Britain. Financial Times Pitman Publishing.

Oba, V. (2011). The Impact of Corporate Social Responsibility on Market Value of Quoted Conglomerates in Nigeria. ICAN Journal of Accounting and Finance, 1(3), 64-72.

Odior, E. (2013). Macroeconomic Variables and the Productivity of the Manufacturing Sector in Nigeria: A Static Analysis Approach. Journal of Emerging Issues in Economics, Finance and Banking, 1(5), 362-380.

Omojimite, B. (2012). Institutions, Macroeconomic Policy and the Growth of the Agricultural Sector in Nigeria. Global Journal of Human Social Science, 12(1), 1-9.

Porter, L., Lawler, E., \& Hackman, J. (1975). Behaviour in Organizations. Great Britain: McGraw-Hill.

Prasad, S., Green, C., \& Murinde, V. (2001). Corporate Financial Structures in Developing Economies: Evidence from a Comparative Analysis of Tha and Malay Corporations. Finance and Development Research Programme Working Paper No. 35. December.

Rappaport, A. (1986). Creating Shareholder Value: The New Standard for Business Performance. New York: The Free Press.

Rodrik, D. (2008). The Real Exchange Rate and Economic Growth. Retrieved from http://www.hks.havardedu/fs/drodrik/Research

Rose, P., Wesley, T., \& Giroux, G. (1982). Predicting Business Failure: A Macroeconomic Perspective. Journal of Accounting, Auditing and Finance, 20-31.

Salawu, R. (2010). The Dynamic Model of Capital Structure and Business Risk of Listed Non-Financial Companies in Nigeria (1990-2006). An Unpublished $\mathrm{PhD}$ Thesis Submitted to the Department of Management and Accounting, Obafemi Awolowo University, Ile-Ife, Nigeria.

Schaltegger, S., \& Wagner, M. (2006). Integrative Management of Sustainability Performance, Measurement and 
Reporting. International Journal of Accounting, Auditing and Performance Evaluation, 233-247.

Shirai, S. (2002). Have India's Financial Market Reforms Changed Firm's Corporate Financing Patterns? Research Paper Series No. 38. ADB Institute.

Sims, C. (1980). Comparison of Interwar and Postwar Business Cycle: Monetarism Reconsidered. American Economic Review, 70(2), 250-257.

Stern, J., \& John, S. (2001). The EVA Challenge: Implementing Value Added Change in an Organization. New York: John Wiley.

Stewart, C. (1991). The Question Value. New York: Harper Business.

\section{Copyrights}

Copyright for this article is retained by the author(s), with first publication rights granted to the journal.

This is an open-access article distributed under the terms and conditions of the Creative Commons Attribution license (http://creativecommons.org/licenses/by/3.0/). 